\title{
Why Indonesians Turn Against Democracy
}

\author{
Nicholas J. Long,
}

London School of Economics and Political Science

\begin{abstract}
Many Indonesians who welcomed the nation's democratisation in 1998 now look on democracy with horror and shame. This chapter seeks to move beyond the focus on corruption and socioeconomic performance, which currently dominates both the literature and public discourse in Indonesia, to examine some of the deeper issues that might lie alongside such concerns, or for which they might serve as an idiom of distress. Pursuing a person-centred ethnographic approach, I show how the appeal of democratisation lies in its promise of new modes of acting and being in the world, and yet these modes of being can turn out to prove so distressing or uncomfortable that the subject turns against democracy altogether. I focus in particular on difficulties and ambivalences surrounding the expression, fulfilment, and disregard of one's desires, opinions, and familial identifications.
\end{abstract}

\section{Keywords}

democratic recession, freedom, Indonesia, person-centred ethnography, political psychology, psychodynamics

Published in:

Joanna Cook, Nicholas J. Long \& Henrietta L. Moore (eds). 2016. The State We're In: Reflecting on Democracy's Troubles, pp. 71-96. Oxford \& New York: Berghahn. 
When Syamsuddin, ${ }^{1}$ a middle-aged Malay with a laundry business, installed his cable TV, it marked a fundamental transformation in our relationship. No longer would we sit in his front yard to sip coffee and discuss the latest neighbourhood goings-on; our conversations were relocated to an airless back room, each of us facing not the other, but a 21-inch screen. I rather missed the outdoor location, but Syamsuddin was in no doubt that the change had been for the better. He was, by his own admission, a cable TV junkie and, like many Indonesians I knew, would while away many happy hours watching Animal Planet documentaries or the National Geographic channel. His absolute favourite things to watch, however, were re-runs of the Obama versus Clinton debates that had been staged in the run-up to the 2008 democratic primaries.

Syamsuddin had been hoping that the debate would educate him in the ways of democratic personhood. He explained to me that he felt that if Indonesians wanted their democracy to be good, they would have to learn from the people of nations such as America, who had been democratic for a very long time. He particularly admired Obama, who he felt could put his opinions across firmly but politely. For Syamsuddin, then, watching these debates was not an exercise in political punditry but rather an exploration of how one might live and act in a democratic state. As he put it, 'I have to learn to think and speak like that!'

Such an enterprise seems to be the hallmark of the project of ethical self-cultivation, at least as the latter has been described in a recent monograph by James Faubion (2011). Emphasising the processual dimension of ethical practice, Faubion insists that anthropologists should pay more attention to the work required to inhabit a role, to 'savour it' and live it to its fullest, rather than reducing their accounts of subjectification to moments of linguistic ascription (ibid.: 65-66, 160). By this light, Syamsuddin was working hard, with Obama as his exemplar, to inhabit the subject position of 'democratic citizen' that 'had become him' by virtue of Indonesia's democratization in the late 1990s. 
This was in 2008. In 2011 I went back to Syamsuddin's house, hoping to understand in more detail the relationship between democratisation and ethical life. He greeted me warmly and, in front of the TV screen, asked me what I was now working on. I answered 'democracy'.

'Democracy?!' he replied, raising his eyebrows in a disdainful way. 'I can tell you all you need to know about democracy! It's no good. No good! Better to have a caliphate. Or a dictatorship.'

His remarks took me by surprise. 'But last time we met, you seemed so enthusiastic about democracy,' I protested. 'We watched Obama together!'

Syamsuddin deflated. 'Oh man,' he said, 'I was hoping you weren't going to remember that. You know, I was so arrogant back then. Man! Man!' He grew alarmed. 'Please tell me you haven't written that I liked democracy in your book! I'm anti-democracy now.'

On May 21 1998, Indonesia's President Suharto announced that he would be stepping down from office. His resignation signalled the end of 32 years of authoritarian rule under his 'New Order' regime, and the start of a new phase of the nation's political life - one characterised as an era of 'reform' and 'democratisation' by both Indonesians and outside observers. At the time, as Joshua Barker (2007: 87) notes, many Indonesia-watchers were convinced that 'the New Order would reconstitute itself in all but name or that the country would descend into communitarian violence'. However, the early 2000 s were instead marked by 'a surprising degree of democratisation' (ibid.: 88), prompting many to hail the country's transition to democracy as a remarkable success story that 'present[ed] valuable lessons for other 
countries' (Aspinall 2010b: 20).

A key dimension of this positive story has been the observation that - whatever shortcomings persist at the level of elite politics or within political institutions - there is tremendous public support for democracy, and a repudiation of the violent and repressive styles of government that characterised the New Order. Tony Day (2007: 2), for example, has argued that 'after 32 years of authoritarian rule under Suharto and his New Order, Indonesians are crazy about many kinds of freedoms (kebebasan) - freedoms that are subjective and sexual as well as public and political', whilst Suzanne Brenner (2007: 35) found 'very few' of the Indonesian women she worked with 'would wish to return to the days of authoritarian rule.' In 2013, Indonesia's former Minister for Foreign Affairs, Hassan Wirajuda, concluded that Indonesians had 'reached a point of no return' as far as commitment to democracy was concerned. 'Maybe 5 per cent [of the population] want a return to authoritarian presidents,' he elaborated, citing 'a poll taken a few years ago', whereas ‘72 per cent of people want democracy’ (Hartcher 2013).

\section{<Figure 3.1: Map of the Riau Islands>}

With such assessments in mind, and drawing on over thirty months of fieldwork in Indonesia's Riau Islands Province (Figure 3.1), this chapter seeks to make sense of a category of people who present a curious ethnographic puzzle. These are people like Syamsuddin who, having once expressed a strong commitment to democratic principles and practices, had now come to view them with suspicion or disdain. Two points should be stressed at the outset. Firstly, not all Riau Islanders shared these sensibilities. Many delighted in democracy; others had always been hostile to the idea that it was the best form of government. Nevertheless there was a significant - and seemingly growing - minority of citizens who were changing 
their mind about democracy as a political form. Understanding why they were doing so is particularly important given evidence that suggests this may be a broader national trend. ${ }^{2}$ Secondly, I am not concerned in this paper with the question of why someone might be opposed to democracy per se, so much as understanding why, having once joyfully participated in the 'eruption of the political' that Byron Good (2012: 528) describes as having followed the resignation of Suharto and which my informants often described as a 'euphoria', someone might now have come to abandon their faith in democracy and thereby adopt what I would describe as a 'post-democratic' subject position. My hope is that this specific empirical puzzle might also raise some interesting contributions to broader anthropological discussions of ethical self-cultivation, how democracy is inhabited and how political subjectivity articulates with systemic change.

\section{A brief history of Indonesian democracy}

Although the suitability of 'Western style democracy' for Indonesian culture had been hotly debated since colonial times, with opponents suggesting its emphasis on rules and procedures left insufficient scope for leaders to exercise their kebidjaksanaan - or 'personal discretion or discernment' (Tsuchiya 1987), Indonesia was established as a constitutional democracy upon its independence. This decision partly reflected the personal commitments of key revolutionaries to liberal democratic principles (Feith 1963: 313), but also a desire to forge Indonesia as the 'social, economic and political equal' of other nations seen as 'modern' (McVey 1994: 4-5). However, when the early years of independence were beset by problems ranging from spiralling inflation to regionalist insurgencies, the President, Sukarno, was quick to assert that 'Western-style democracy' was to blame. ${ }^{3}$

Thereafter the nation witnessed successive attempts to craft a superior political system. Having suppressed regionalist rebellions in coalition with the Army, 1959 saw 
Sukarno introduce a new system of rule, which he termed 'Guided Democracy'. This was a system of government based not on the principle that 'fifty per cent plus one are always right', which he associated with 'Western individualism' but rather 'real Indonesian democracy' in which decisions were based on consensus and discussion, but steered by the discerning wisdom of a revered and trusted leader (Feith 2007 [1962]: 515; Tsuchiya 1987: 213-5). Parliamentary institutions were marginalised from the political process, with most issues discussed at meetings of the presidentially appointed National Council and at ad hoc conferences of military commanders. Civil liberties, such as freedom of the press, were curtailed. 'To many observers,' Feith (1963: 326) notes, 'the new political order looked like dictatorship'.

As the 1960s progressed, however, there was increasing dissatisfaction with Sukarno's management of the rapidly weakening economy, his belligerence towards Malaysia, and his increasing closeness to the Indonesian Communist Party. Following an alleged Communist coup attempt in September 1965, the then military general Suharto was given authority by the President to secure order across Indonesia. Through a series of manoeuvrings he purged the military, government, and parliament of pro-Sukarno elements, stripped Sukarno of the title of President, and installed himself as the ruler of Indonesia. Mass violence broke out across the nation, as alleged communists were massacred in their thousands. The nation having been 'purged' of this ideological 'threat', Suharto claimed that his 'New Order' regime would allow Indonesia to enjoy a 'healthy democracy' (Hooker 1993: 277), which he named 'Pancasila Democracy' after the nation's civic philosophy.

As a system 'originat[ing] from an understanding of family values and mutual cooperation', and in which 'opposition groups found in liberal democracies are unknown', Suharto's (2003 [1967]: 38-39) conception of ‘Pancasila Democracy’ bore many resemblances to the paternalistic 'Guided Democracy' that it superseded. Regular elections, 
referred to as 'festivals of democracy' (pesta demokrasi) did take place, but Suharto used his authoritarian powers to interfere with the working of the two opposition parties that he allowed to run against his own Golkar party, ensuring they never posed credible challenges to his power (Slater 2007: 102). All the while, state discourse, including that taught in the national curriculum, emphasised the incompatibility of liberal democracy with the Indonesian national character, and cited the 'anarchy' and 'incompetent' governance that Indonesia had experienced in the 1950s as evidence to that effect (Bourchier 1994).

Nevertheless, there were activist voices lobbying for more transparent, liberal and democratic forms of governance: an argument justified both on first principles and on the concept of securing membership in 'world culture' (Crouch 1994; Soetjipto Wirosardjono 1994). When the protests of self-styled 'pro-democracy' activists, together with the devastating devaluation of the rupiah, prompted Suharto to resign, this liberal conceptualisation of 'democracy' became dominant. Substantial reforms were passed to support the prospect of free and fair elections, a dramatic decentralisation programme was implemented in the name of supporting democratisation (this had particular implications for the Riau Islands, which became a new province as a result), and the New Order regime was retrospectively seen - whether affectionately or with horror - as a system that had been 'authoritarian' (otoriter). ${ }^{4}$

For the majority of Riau Islanders alive today, then, 'democracy' as they now know it is something that they had heard a great deal about - both positive and negative - without having ever directly experienced it in their lifetimes prior to 1998 , and certainly never as a stable political system. This was something that people in the province were acutely aware of, and so, alongside the institutional and civil liberty indicators that have typically been synonymous with 'third wave' democratisations, they also spoke of 'democratisation' when describing the refashioning of the ways in which one would relate to themselves and others. 
Issues such as how citizens interacted with and related to the political classes were now open for creative re-thinking (see e.g. Simandjuntak 2009), as were questions of how to appropriately articulate and listen to political wishes, and how to inhabit and 'savour' one's new found freedoms.

Such efforts, exemplified by Syamsuddin's training himself to 'think and speak' like Barack Obama, but also various efforts to 'democratise the workplace', 'democratise the family', or simply become a new form of political subject all represent conscious vernacularisations of democracy - to borrow a phrase coined by Lucia Michelutti (2007) to describe Indian engagements with democratic forms of life. Unlike in the Indian case, however, it would be wrong to say that Riau Islanders' experiments in 'vernacularisation' have necessarily led to democratic ideas being 'embedded in.... social and cultural practices [and] entrenched in the consciousness of ordinary people' (ibid.: 639). Such analysis implies a depth and finality that stands at odds with many of my informants' dramatic changes of heart. Instead, I will argue, these vernacularisation processes - which we can also understand as processes of acquiring the 'dispositional competencies and affective and perceptual orientations' that Faubion (2011: 65) sees as a prerequisite to the occupancy of a fully realised subject position - were often presented to me as ones that had short-circuited because of the new relational dynamics and forms of sociality to which they had given rise. Democratic citizenship was then abandoned as an ethical and/or aspirational telos ${ }^{5}$ as Riau Islanders, whilst still fundamentally envisaging themselves as liberal subjects entitled to adjudicate between alternative political systems, began to place their hopes in the prospect of alternative political forms.

Theoretically, this phenomenon sets a challenging agenda for the anthropology of democracy. Many fine studies within the subfield have traced the forms of disillusionment and dissatisfaction that emerge from incompatibilities between liberal democratic models of 
politics and locally prevalent notions of moral behaviour, personhood, and leadership (see e.g. Ferme 1998; Hickel 2015; West 2008). However, such a line of argumentation cannot be straightforwardly applied to post-democratic Riau Islanders like Syamsuddin, since it would struggle to explain the intense initial identification with democratic ideals from which they are now moving away. A model is required that is more attentive to the unfolding process and changing momentum of the ethical life of democratic citizens and that can account for how affinities and incompatibilities with the ideal of 'democracy' are themselves socially produced.

At present, scholars tend to explain such emergent feelings of dissatisfaction with democracy in one of two ways. The first, which is the dominant approach within political science, argues that citizens are 'disappointed' when democratic statecraft fails to deliver the quality of governance to which they aspired. If economic growth is limited and corruption is high, the efficiency of a strongman or CEO-style technocrat can tempt citizens' aspirations away from democracy (Chang et al. 2007; Diamond 2008; Kurlantzick 2013). But this analysis, as Carothers (2009: 12) notes, struggles to explain why concerns with governance and economic development should come to outweigh the benefits of free speech, a free press, and checks on the powers of the military and the police. Yet whilst Carothers sees this flaw in his colleagues' reasoning as a reason for scholars to temper their democratic pessimism, I see it as an invitation to interrogate more precisely what issues matter most to citizens when they reflect on democratic forms of sociality - and why. Indeed, when we pay closer attention to both the ethical imagination and the concerns that dominate Riau Islanders' accounts of their biographical transformations under democracy, we can quickly see that the 'freedoms' associated with democracy may, over time, come to be experienced as less positive than Carothers - or Indonesianists such as Brenner (2007) and Day (2007) - might suggest. I commonly heard Indonesians lament that the self-interest and enjoyment of others, or their 
own 'selfish' desires, had had a destructive effect upon both political and social relations; others reported that democratisation had made them 'too free'.

So why should democratic sociality feel so unpalatable? A second approach to democratic dissatisfaction, exemplified by Hansen's (2012) recent ethnography of the South African township of Chatsworth, argues that a transition to democracy necessarily elicits feelings of melancholia. By this logic, the dissolution of a repressive regime (such as that of South Africa’s apartheid era) induces a Hegelian ‘unhappy consciousness' (ibid.: 12), presenting citizens with the burdensome responsibility of authoring their own sense of self and purpose. The result, Hansen argues, is a 'pervasive sense of loss and displacement' anchored to melancholic behaviours of 'self-reproach and self-reviling' (ibid.: 16). And while in Chatsworth, this atmosphere of melancholia is compounded by a sense that nostalgia for apartheid can never be articulated in those terms (ibid.: 12), in other contexts - such as postSuharto Indonesia, where the memory of authoritarianism is less deeply embedded in a politics of racial inequality, ${ }^{6}$ the possibility of voicing authoritarian nostalgia seems immediately more thinkable. Where Hansen's argument makes a substantive advance to the anthropology of democracy is in his willingness to place the affective and psychological consequences of democratisation at the heart of his account. However, his argument is compromised by its assumption - evident in his equivocation of authoritarianism with Hegel's lord-bondsman dyad - that those living under authoritarian rule have such little sense of alternative possibilities that life after liberation necessarily presents an existential burden. It thus struggles to accommodate situations such as Indonesia, where citizens entering the nascent democracy carried explicit, if impressionistic, visions of the democratic subjects that they wanted to become.

Rather than following Hansen in seeing the negative affect of democratisation as an inaugural element in analysis, we should instead examine how specific attempts to acquire 
the competencies and orientations of a 'democratic citizen' may themselves generate unexpected and painful dilemmas. It would then not be the intrinsic burden of self-making, but the successes, failures, and challenges that arise from particular instances of self-making which generate affects (melancholic or otherwise) that influence both a subject's disposition towards the world, and towards democracy, thereby shaping the horizons of its future selfcultivation. This approach to democracy's inhabitation requires a biographically-grounded understanding of subjects' changing engagements with the concept as its referent moved from an imagined prospect to a concretely experienced and enacted form of life. Personcentred ethnography, which examines 'how the individual's psychology and subjective experience both shapes, and is shaped by, social and cultural processes' (Hollan 2001: 48) seems like a promising way forward. However, it raises questions as to how to best generate ethnographic description that is attentive to idiosyncrasy whilst still able to make broader claims about a general situation.

Here I draw inspiration from Nancy Chodorow's (1999) analysis of gender as both a 'cultural and personal construction'. Chodorow observes that individual experiences of gender can focus on quite different issues: some of her respondents are preoccupied with body image, others with anger, others with status, yet all these 'personal meanings' of gender are nevertheless recognisable as part of the late twentieth-century American genderscape (ibid: 88-89). From a whole set of ideas about gender that circulate in discourse, certain elements have come to be 'emotionally particularized' (ibid.: 215), and projectively and introjectively recast over the subject's lifetime, through the specific emotionally charged matrices of relations in which he or she is embedded. In this way, cultural and linguistic categories are given 'personal animation' (ibid.: 76) so as to generate a way of inhabiting a gendered subject position that is uniquely individual but nevertheless recognisably American. 
Building on this argument, it seems productive to investigate how similar kinds of personal meanings might also surround political life - a field as saturated with concerns about self-expression, acceptance, membership and status as is gender performativity. As such, we might expect to observe uniquely individual but nevertheless recognisably Indonesian flavours to how Riau Islanders inhabit the subject position of 'democratic citizen' - and indeed, how willing they are to continue inhabiting it. Through a more individualised analysis, we can develop richer and more diversely textured understandings of postdemocratic sentiment (and indeed democracy's inhabitation) than those afforded by explanations focused on the quality of governance or Hansen's unduly deterministic psychological model. Yet while personal meanings are precisely that - personal, and therefore idiosyncratic - cultural, political and institutional arrangements not only constrain the ideas that might become integral to the subject's sense of self, they also encourage and institute particular forms of sociality - particular emotionally charged matrices of relations in which certain meanings of political life, self-expression and 'free' action become especially likely to be forged. Such an approach promises a more psychologically accurate portrait of why subjects may come to find democracy difficult to inhabit even in those cases where they were initially strongly drawn to democratic social imaginaries and value systems.

\section{Fio's Story}

The first time I met Fio, he didn't make much of an impression on me. I'd been invited home by his younger brother Iyan - the one their father was disappointed in and who locals said gleamed like a knife, but cut like one too - and quickly found myself captivated. Iyan was an engaging host, regaling me with tales of dodging wild boar on his motorbike at night, while Yanto, their lodger, offered fascinating descriptions of trapping the boar in the jungle, tying their snouts with twine, and rowing them to market for export to Singapore. And then there 
was Fio, the oldest surviving sibling, approaching thirty and still not married: a wiry, nervy man who stood on the edges of the group and only laughed after someone else had already begun to.

Fio did tell me one story - of how, as well as setting up a catfish farm, he'd started working on a small island to the south, teaching maths and computing to children under twelve. This wasn't a story of pigs and adventure, just mundane detail: it was a long journey to the island, the boats were only fortnightly, hardly anyone lived there, he didn't know what to do with himself, he went fishing a lot. He showed me some photos. Fio with a fish. And then another one: Fio, trying to smile, but with his brow so furrowed that it looked like a grimace. That's how he was feeling on the journey, he told me. I did think there was something arresting about the picture, but then Iyan began to share anecdotes of his misadventures when fishing, and I quickly forgot all about it. Then out of the blue, a few weeks later, I received a text message from Fio. He was in Tanjung Pinang for a training seminar and suggested we meet for dinner at his hotel.

Fio had been hoping to order fried catfish - his favourite - but it was off the menu. So we opted for kwetiau goreng, my choice, a hearty mix of flat rice noodles and seafood fried with spices and treacly soy sauce. It tasted good to me, but Fio was not touching his food. He seemed uncomfortable; nervous. I asked him what was wrong. He liked me, he said shakily, and wanted to be friends with me, but he was aware that I didn't yet know what he was 'really like'. If I knew 'the truth about him', he feared, I would no longer want to know him. 'When I was younger,' he said, his voice almost a whisper, 'I used to be active in... democracy.' I didn't know how to respond. I took a mouthful of food to fill the silence; Fio poked a prawn through the tarry mass of noodles congealing on his plate. He gave me a piercing, earnest look. 'I was selfish then. It was arrogant of me. Now I am focusing on something much better. I'm doing this catfish thing.' 
When Fio had graduated from Senior High School in 2004, the very last thing that he wanted to do was pursue further education. His mother, however, had different ideas. She had grown up in poverty on the island of Java and her relocation to Lingga - under the government's ill-fated 'transmigration' scheme - had done little to ease her family's privations. ${ }^{7}$ Fio's mother was adamant that her son should not suffer the poverty that she and her husband had, and so she threatened him with a terrible curse. 'She told me that if I didn't get an undergraduate degree, she would disown me as her biological child,' Fio told me, 'She really valued education. Well, of course, after I heard that, I had no choice. She was threatening me with the most terrible thing that a mother could. So I went to Sumatra.'

Fio enlisted in an economics program at a private university in a Sumatran city. It was here that he got involved in the world of political parties, campaigning on behalf of electoral candidates and organising public demonstrations in order to fund his studies. He told me that before starting this work, he had always been a very quiet and reserved person, but he forced himself to change. However, for reasons that he struggled to articulate, his shift to a more outgoing disposition had made him anxious. He worried a lot during this period and found he always craved human company in order to get a sense of security.

Fio's time at university also afforded him an opportunity to meet idealistic students from across Sumatra who were passionate about forging a more ethical and accountable Indonesia. They focused on trying to achieve concrete improvements within their campus, including reform of the Economics Faculty, where the Dean stood accused of corruption and malpractice, such as requiring a bribe to sign letters confirming students' graduation. Because this was 'happening too often and becoming too apparent', Fio and his friends decided that something needed to be done, and that it would be appropriate to exercise their democratic rights by staging mass demonstrations demanding the Dean's resignation. Given his previous 
experience in co-ordinating demonstrations, Fio's role was to assemble a mass of students for the protests - something he told me with a guilty look.

'When I did the demo we thought if we came together we'd be able to get change in the Faculty,' Fio explained, 'a new Dean. And yes, we toppled her. But, that's the thing for me. All we did was produce ego and selfishness. We got a bigger ego, rather than improving the Faculty members. Maybe that Dean could have been a worker who was better than she was. That's what our demo should have been making her aware of! It should have been giving the campus staff advice and feedback so that they would get a new way of thinking and would want to develop what they have.'

Reform Era Indonesia's culture of public demonstrations has been one of the more controversial aspects of the nation's democratisation. This is partly because of the risk of violence, but also because of the widespread concern that demonstrations might not reflect the desires or opinions of the people who were demonstrating (typically for pay), but rather the agendas of the demonstration co-ordinators, themselves presumed to be in the service of self-interested elites who were staging the demonstration in order to further their own political careers by, for example, discrediting a rival (Bubandt 2014). ${ }^{9}$

My own experience was that demonstrators in the Riau Islands were quick to portray their links with political figures as strategic alliances over which they retained control. In their view, there was nothing wrong with receiving financial assistance from elites to showcase the failings of a rival if that demonstration might also contribute to social justice. However, several friends warned me not to believe such claims, suggesting they were simply a rehearsed defence that elites had prepared the demonstrators to give to any researchers or journalists enquiring about the demonstration. The general opacity of sincerity in democratic forms of mobilisation was enough for many to eschew an involvement in politics altogether. They liked their social relations to be 'clear' (jelas), they said, but in democratic politics 
everything was murky (gelap). The 'interests' (kepentingan) of the powerful could hijack everyday forms of sociality and friendship - something these friends were keen to avoid.

Against this more general background of moral anxieties surrounding demonstrations, Fio's own narrative of discomfort with his actions is all the more striking for its idiosyncracy. Though he could hardly be described as being proud of his general involvement in democratic politics, what led him to decry his involvement as shameful was not the purchase of his services by local elites. It was the success of a demonstration in the service of a campaign that he considered to be both morally justified and of practical urgency given how important it was for him to secure his own graduation certificate. Rather than being uncomfortable that he had become a vehicle for the interests of others, it was the successful realisation of his own 'selfish' desires that had provoked his anxieties.

Our hotel dinner suggested that these anxieties were profoundly relational. Fio was worried I would judge him - and reject him. That makes sense in the context of a social milieu in which demonstrating is viewed with considerable ambivalence, and I had encountered similar discomfort before. Robet, for example, a politics student at a local university, was quite articulate about his own discomfort at having participated in several student demonstrations. 'I don't want to be anarchistic', he told me (the term has connotations with violence), 'but students need to be critical, and sharp in their criticism!' But while Robet felt uncomfortable about the stigma surrounding an activity he nevertheless felt to be justified, Fio's ambivalence went beyond moral ideologies and social imaginaries of 'the demo', involving much more personal responses to the expression and fulfilment of his own desires.

Looking over my conversations with Fio, a striking theme was that the fulfilment of his political desire - to topple the Dean - had not proven satisfying. This was evident less in the reporting of the demonstration than in its repeated juxtaposition with alternatives that 
were proven or imagined to be more affectively satisfying. His counterproposal of giving the Dean 'feedback' was the first such example, but he later drew a contrast between his involvement in 'democracy' and his ongoing attempts to develop a catfish farming business:

Fio: I'm doing this catfish thing, and if a government department (Dinas) is interested and wants to help, they can come, they can help, and we'll be able to work together. I think it's better than if I did the sorts of things I used to. And God willing, there's someone from the Department of Farming who's interested! [...]

They just have to print out their operational data. They want to help, but the money isn't here yet, maybe [next month]. And then I can build up the business, even though I'm only getting fifty per cent [of the profits]. That, for me, has generated a bit of enthusiasm amongst my friends, but also enthusiasm within my own self. I'm doing something and there's also a person - a Department - that wants to support what I'm doing.

Here, the prospect of 'working together' with the government by means of receiving an agricultural subsidy, was appealing not only because it promised to provide Fio with money (which he needed, having set up his catfish pond on credit) but also because it 'generated enthusiasm within his own self' (memberi semangat pada diri Fio). There was something affectively satisfying about being involved in relations of mutual care and support, whether those of political sponsorship or relations of feedback, that had been absent from toppling the Dean.

How then should we account for the transformative feelings of horror and shame that fell upon Fio, and that seemed to still be affecting him quite viscerally as he projected them onto me? One answer to this question - what I call 'the political ideology explanation' - 
would emphasise how, under 'Pancasila Democracy', mutual support, working together and co-operation were all widely valorised in national ideology, whilst 'anarchistic' expressions of dissent were discouraged. Could it be that Fio, still subjectivated by those discourses (or their contemporary parallels), found himself torn between New Order and post-Suharto visions of ethical politics and so eventually came to look back on his actions with regret? Possibly. But this kind of explanation, premised on enduring cultural/political values simply raises further questions, such as why similar tensions didn't also run through his other demonstrations, why it was the New Order values (and not the democratic values) that won out, and why the event was remembered in such a viscerally disturbing way.

The emphasis that Fio himself placed on selfishness, and its juxtaposition with relations of care and mutual support suggests that a productive alternative perspective might come from an approach that historicised Fio's relationship to his own desires within the context of the emotionally charged relationships that he experienced throughout his life. Certainly, there seems to be sufficient evidence in the life histories that I collected from both Fio and his relatives to suggest that Fio's relationships to his desires had long been problematic for him (and problematised by those around him). There was his history of having been 'very quiet', and his extreme anxiety and 'need to be around people' once he started getting involved in a job that required him to express views as if they were his own. No wonder travelling to a remote island was enough to shadow his face with a dark frown. There was the way he always let kids in his classroom pop out for drinks and snacks if they wanted, because 'nobody likes a strict teacher'. Even his presence in Sumatra was a result of his suppressing his own desires in order to please his mother and secure his status as the favoured child. Perhaps this pattern is unsurprising. According to his siblings, and by his father's own admission, Fio had been brought up under a parenting style which encouraged 
the children to disavow their own desires and preferences in favour of what their parents thought would allow them to escape the poverty of the transmigration village.

Indeed, Fio's childhood seems to have exemplified the pattern that Keeler (1983: 155) documented in a classic paper on Indonesian conceptions of shame, in which older children in Javanese families were expected to suppress their own desires (previously heavily indulged) in favour of those of their younger siblings. For Keeler, learning that one should disavow one's desire in this way marks an inaugural discovery of social fear, and the recognition that inappropriate behaviour - one's own or others' - should make a child ashamed. Clinical psychologists in America have also found that patients who were forced to forego their own wishes, in the face of emotional violence on the part of their parents, may grow up to experience deep ambivalences towards their own desires: feeling a strong wish to express them and yet feelings of crippling guilt and selfishness when those desires are fulfilled (Davies 2009, and see Chapin 2010 for a comparative ethnographic case). Fio still claims that his 'biggest weakness' is that he is 'quick to make friends, and then quick to follow them and will do whatever they suggest', a claim which suggests a pattern of disavowing his desires to secure the approval of others continues, almost impulsively, to characterise many relationships in his life. Even his friendship with me involved him putting me in a position of power and judgement over him from a very early stage.

We can thus see how the radical new opportunities for expressing one's desires in a socially approved form that an involvement in democratic politics presented might have proven attractive to Fio and yet left him feeling uncomfortable and guilty upon their eventual fulfilment, (particularly, perhaps, after this led to the firing of an authority figure). By contrast, the mode of political engagement that Fio now aspired to was one of 'feedback' and 'working together' where he might be able to express his desires in efficacious ways without disrupting harmonious, hierarchical relationships. It should be stressed, however, that such a 
reading of the material is not really an alternative to the 'political ideology explanation' described earlier so much as a complement to it, since the parenting practices that Keeler ascribes to 'Javanese culture' were themselves powerfully shaped and reinforced by the New Order, which premised its authoritarianism on 'family values' whilst simultaneously propagating a much more authoritarian vision of the family than had previously been in circulation (Brenner 1998: 232-257). Several male Riau Islanders testified they had 'ruled' their households 'as if they were Suharto', 'with an iron fist', 'in a military style' or 'with coercion and force'. They had seen Suharto, 'the father of the nation', as exemplifying the kind of firm leadership that they should also enact as fathers, even though many now regretted this behaviour and were struggling to reorganise their family lives in more 'democratic' ways. Of course, not every family will have had this character, and not all such families will have produced subjects as conflicted about their desires as Fio. Yet the promotion of particular family forms and values makes these kinds of psychological dynamics especially likely, adding a further layer of understanding to the analysis of why some Indonesians have a conflicted relationship to democratic practices that involve the open expression of their opinions and desires despite declaring themselves intellectually convinced by 'democratic values'.

Further support for this argument comes from examining how families and childrearing were themselves conceptualised as sites of democratisation, and by examining which vernacularisations of democracy proved most popular and sustainable. Interestingly, the more stable variants typically involved a vision not unlike Fio's preferred sociality, emphasising 'feedback' and 'working together'. Whilst more radical models premised on majoritarian suffrage were practiced by some families, one Chinese schoolgirl explaining how her family held 'elections' whenever big decisions like where to go on holiday needed to be made, such a practice - in which the father's 'vote' could be easily trumped by the 
collective will of his children - was relatively uncommon. The model of democratic kinship that found much wider support kept the father as 'head of household' and ultimate source of domestic authority, but nevertheless involved a significant change in the structure of relations. A Batam Pos feature on how to be a democratic family (Ratna Irtatik 2012) cites one father, Darno, who explains how he allows his wife and children the freedom to express their desires. As long as he deems these desires to be 'good and proper', he (and all family members) will support them as much as possible. Thus, when his wife decided she would like to start a business, Darno offered his full support - but only once he had decided that this was a good and proper thing to which to aspire. He describes his style of being a father and husband as one that 'opens opportunities for responsible freedoms'. contrasting it with his own 'military-style' upbringing. Clearly, then, how to balance individual desires with deference to established authority stands out as an ethical problem for Darno and his family, as they embrace Indonesia's democratisation. More interestingly still, this has been assumed to be of sufficient relevance to the newspapers' readership to be the centrepiece of a feature on how to become democratic.

In Darno's case as much as Fio's, the initial embrace of democracy, and the trajectory of its subsequent vernacularisation or rejection is explicable not just in terms of values or ideologies that were disseminated under the New Order, but embodied and affectivelycharged modes of relating to oneself and others that were instituted during that period and which it could feel deeply uncomfortable to break or shake off, even when one might have intellectual sympathy for alternative 'democratic' values. And for Fio himself, these difficulties had led the very concept of 'democracy' to become one that he now wanted to distance himself from. He told me that he was making sure he would have no more involvement with 'democracy' and would instead focus on developing his business, and that he would be warning his friends off getting involved in democratic life. These powerful 
feelings that stemmed from just one formal dimension of democratisation had come, at least for now, to inflect his assessment of the entire process of reform.

\section{Maznah's story}

For Fio, political life had become charged with personal meanings that had led him to adopt an outlook with considerable post-democratic potential. But there were also many people who did not only express dissatisfaction with democratic forms of life: they explicitly longed for the reintroduction of a more authoritarian form of politics. These sentiments were sometimes expressed in terms of the desire for a theocracy (usually an Islamic caliphate), but more frequently as a wish to return to 'an authoritarian regime's like Suharto'. This latter phenomenon has often been analysed in terms of a nostalgia for the New Order regime, prompted by the perception that governance was of better quality in the past, especially as regards the management of the economy (Mietzner 2009), while the former is often proposed by its Indonesian advocates as a novel solution to these very same problems (Hasan 2008: 38). However, my ethnographic materials show that authoritarianism need not be desired in its own right. Rather, in a context where radical socialism remains extremely unpopular (a legacy of the killings of communists in the 1960s), authoritarianism may represent the only viable alternative to a democracy that has acquired a personal meaning that makes the status quo psychologically untenable. Once again, to understand this, we must appreciate how democracy can threaten the self by assaulting the unconscious or conscious identifications and relationships that are fundamental to Riau Islanders' senses of who they are.

A Malay housewife in her seventies, Maznah told me that she had 'always been interested in politics'. She wasn't certain where that interest had come from, but suspected it could be traced to the influence of her father. This man, Batin Osman, had been the headman of a small island to the west of Bintan during the colonial period - an island which I will call 
'Pulau Empat' to protect Osman and Maznah's real identities. Maznah had been very close to her father during her childhood: she had listened with interest to stories of his work, and sometimes accompanied him on his journeys to meet with Dutch officials or other 'important people'. However, her family was thrown into turmoil in 1942, when Batin Osman was murdered by a Chinese plantation worker who he had intercepted committing a theft. Shortly afterwards, Maznah moved to Tanjung Pinang.

Maznah's first active foray into 'politics' (as she termed it) had been in the early 1960s, when Indonesia was in a state of Confrontation (Konfrontasi) with Malaysia regarding its proposed expansion to include Singapore, Sabah and Sarawak. 'I decided I would join a group of volunteers,' she explained. 'There were four men, and then two women - me and another - and we spent our time hunting for Malaysian spies in the jungle. I didn't get any wages for the work, but I didn't mind. It was important to do it for the good of my own country. I'm lucky my husband was never a jealous man. If he had been, he might have forbidden me from going into the jungle late at night with four other men!' She laughed, and told me that ever since her jungle outings she had found herself increasingly interested in politics and affairs of state.

When reformasi began, she seized the opportunity to get involved in political campaigns to 'try and get the very best for the Riau Islands'. She had helped the former regent of the Riau Archipelago, Hoezrin Hood, come up with a strategy to lobby for provincial autonomy, and she had been an enthusiastic participant in several rounds of electoral campaigning. But here the emphasis was very firmly on the 'had'. We were talking in August 2012, just a few months before Tanjung Pinang's mayoral elections, and speculation over who should and would win the election was reaching a fever pitch. Yet Maznah, despite having been approached by several of the candidates' campaign teams, was refusing to play any role in this election. 
'Democracy! I don't want anything more to do with it!' she exclaimed. 'Did you know that at the last gubernatorial election, I did a lot of campaigning for one of the candidates? I attended his strategy meetings, discussed policies with him. One night I stayed at the meetings in Batam so late that I had to be escorted back by a private speedboat.' There was almost a hint of pride as she recalled this - or at least a nostalgic fondness - before her voice hardened. 'But that didn't count for anything!'

In the run up to the election, the campaign team had made a pledge that if their candidate received a majority of votes on Empat, he would repair a local mosque which was in an extremely poor condition. The walls were crumbling, the roof was leaking, and this was causing great distress to Empat Islanders who could not afford to repair the mosque themselves. Maznah spent several weeks campaigning in Empat and the surrounding islands, and she placed a heavy emphasis on the fact that a vote for this candidate would be a vote to restore the mosque to its former glory. At the election, Empat Islanders voted overwhelmingly in favour of the candidate Maznah was supporting, and she was convinced this was due to her effective campaigning activities, and the fact that she was well-known and respected in the region, especially by people who could remember or knew of her father.

Several months after the election, however, the residents of Empat contacted Maznah to complain that the mosque was still in a state of disrepair. No steps appeared to have been taken to improve it. Maznah was horrified. 'Nick,' she explained, 'you know as well as I do that I'm an old lady now. If I lie, then all my life and everything that I have done in it means nothing.'

There were several reasons for Maznah's distress. Lying, or telling an untruth, was something she considered a serious sin, capable of annulling a life of good deeds (see Long 2013: 77). But it would also damage her reputation, along with that of her father's name. She instantly went to visit the candidates and told them how angry and upset with them she was. 
A week later, sand started to arrive and within a short period of time the mosque was repaired. The damage had been mitigated, but Maznah still felt very embarrassed about the incident and angry that she had been turned into a liar by her involvement in the political campaign. Her integrity as a campaigner had been placed in the hands of a team who actually did not care about her or the mosque on Empat at all. She told me she was not going to get involved in campaigns ever again, and started warning her children off any involvement in democracy. Not only had the Empat incident forced her to realise how potentially deceitful and insincere political candidates could be, it had also shown her how easily the reputations of good people could be marred by their entanglements in the democratic process. The idea that something of this kind might happen to one of her children or grandchildren horrified her. She would vote - because she felt it was her duty to do this while democracy was in place in Indonesia - but she was hoping that at the next Presidential election 'somebody good' would be elected and would then outlaw any further elections so that Indonesia could 'get on with developing' as it 'had under Suharto'.

The Empat Island case is in many ways a classic example of the clientelistic politics that has been claimed to characterise direct elections in democratic Indonesia, but Maznah's story highlights the poverty of reducing the system purely to a series of instrumental and selfinterested transactions (cf. Palmer 2010). Certainly Maznah would have received payment for her activities in the governor's campaign team, but her own account shows how she viewed them not only - and indeed not even principally - as a means of securing income, but also as the latest expression of a 'political' sensibility that she had been cultivating throughout her life, and which was closely associated with her memory of her murdered father. Part of the pleasure of campaigning in Empat, I sensed, was that it allowed Maznah to enact the role of a beneficent sponsor and leader looking after the islanders (much as her father would have done, when working as a batin), even though as a housewife she was structurally 
disempowered from doing so unless acting on behalf of others. As with her spy-hunting in the jungle, service to political institutions and organisations became an integral means of securing her own sense of political efficacy. This was the personal meaning that 'doing politics' carried for Maznah, reflecting an individual and emotionally particularised animation of cultural ideas about leadership and the provision of service and resources that have long been in circulation in the Malay World (Milner 1982: 23-24).

Yet the debacle that had unfolded over repairing the mosque had served to threaten the very understanding of her political self that democratisation had initially seemed to nurture. As a consequence, democratic politics quickly shifted from being an appealing object of contemplation, that would allow her to use her influence to improve collective wellbeing on Empat, to a dangerous endeavour that was threatening to 'good people'. The emotional tonality that the concept of 'democracy' acquired was thus once again coloured both by the personally-motivated ways in which Maznah had sought to experiment with democracy, as well as by events having unfolded in a way that threatened the things that were of most importance to her image and experience of her self: her 'good name', her relations with the islanders of Empat, and her perceived obligations to (and identifications with) her deceased father. Maznah's horror - so intense, I think, because it threatened so deeply her core sense of who she was - led her to go further than simply disengaging from political campaigning. Recognising the potential for similar traumatic experiences to befall 'good people' in the future, including those about whom she cared very deeply, she was now actively hoping for the day when democracy could be overturned. But this was not because of the positive features she associated with an authoritarian, election-less regime. She just wanted democracy, as she had come to know it, to stop.

\section{Syamsuddin's story}


There were further cases where the proposed alternative to democracy was desired not simply as a negation of the democratic order, but because the troubles of democracy had prompted an identification with its propositional substance. Syamsuddin, the man with whose story I opened this chapter, had found the forms of sociality engendered by experiments with democracy to be problematic after he had joined the local branch of the Islamic Prosperous Justice Party (Partai Keadilan Sejahtera, PKS). He had actually wanted to be involved in political life for a long time, but was too scared to join a party under the New Order. It was possible that another party member might actually be a communist, and he would then be seen as someone who fraternised with communists (in a political party, no less), which would make him vulnerable to imprisonment or assassination. From an early age, then, he had felt that the collectivity of collective political mobilisation could be a danger as much as a benefit. He kept his opinions to himself, and read widely. However, under democratisation, where even communists could express their views freely, such dangers seemed unlikely, and he decided it was time to realise his long-held ambition. Although at the time he joined up he had emphasised that joining the PKS could be a way of improving the Riau Islands (and by extension Indonesia), he later told me that he had chosen to join as 'a kind of personal test':

Was I compatible with the life of a political person? What was it like to be a political person? I had once heard that in politics there are no friends and there are no enemies. Do you believe that? Well, it's true! All you have is self-interest. And that's not a problem if we're on the straight path. Because we don't want to follow another person when he takes us on the wrong path, just because he is our friend. But does democracy put us on the straight path? No. 
As with Fio, then, the lifestyle facilitated by the forms of politics made possible by democratisation was one that involved a distinctive new way of relating to self and others, one that was more radically individualised and anomic ('there are no friends and no enemies') and which led to a heightened sense of one's own 'self-interest'. While it was this very fact that became troublesome for Fio, Syamsuddin's experience was different.

His early experiences with the PKS had been wonderful. The members of the local branch used to gather in each other's houses. Syamsuddin reminisced as to how they used to talk about 'important issues: the weaknesses of Muslims, why are many Islamic countries are trailing behind the West, things like that. We concluded the problem was that they were no longer following the Qur'an and the Sunna - Islam had become their identity but not their religion!' Then it was the 2008 local elections, and the incumbent mayor, Hj Suryatati A Manan, wanted to stand for re-election. Symasuddin was adamant that she would be a bad choice. 'In Islam, it's very clear,' he explained, 'women cannot be leaders. If you think about it, women, they're a little bit soft (lembut). They're weak. They're emotional. And leaders need to be firm. So of course I said that we shouldn't support her.' But other members of the party wanted to. Endorsing Suryatati would lead to the PKS securing a sizeable amount of money, and - given that she was widely predicted to win the election by a comfortable margin -put the PKS in a very strong position in local politics. 'I tried to explain that this was a sin,' Syamsuddin told me, 'but nobody would listen. I didn't want to go to hell - I had to leave. But it showed me how I arrogant I had been. I had thought I could use democracy to help get Indonesia on the straight path. But there is nothing to democracy other than self-interest and majority rule. That's what makes it dangerous.'

Syamsuddin's difficulties with democracy can be traced in part to the changing role of Islam in his life - particularly the influence of an inspirational lecture he had heard from a visiting cleric who had claimed that, at the end of the world, Muslims would be divided into 
seventy-three groups. Only one of those groups - those who had followed Islam perfectly would be allowed into paradise. This had made Syamsuddin much more anxious about enforcing an orthodox position on issues such as female political candidacy than he might previously have been. Interestingly, though, Syamsuddin's initial response to this new horizon of understanding had been to try and use democratic structures, and in particular his membership of an Islamic political party, to build commitment to a more orthodox, scripturally grounded Islam within his home community. This was precisely what the long PKS discussion sessions had been oriented towards. His problem came when his fellow partymembers broke ranks and, from his point of view, sacrificed their unswerving commitment to the Qur'an and the Sunna in favour of their own 'self-advancement'. (For their part, other local PKS members asserted there was no theological problem with supporting a female candidate).

While he disparaged these developments as caused by the self-interest of others, and a flaw of the majoritarian principles at the heart of democratic deliberation - itself a trope that had been regularly aired under Sukarno to justify his guided democracy (Feith 2007 [1962]: 515) - Syamsuddin was quite evidently disappointed with more than just the behaviour of his colleagues: he was frustrated with the way that democracy had stripped him of the capacity to impose his own vision of the 'straight path' on those around him. Although he now recognised that it was 'arrogant' of him to imagine that he could have done this, his response was not to adapt a more measured approach or set himself a more modest goal, but rather to phantasmatically identify with the prospect of campaigning for a caliphate, a state where, in his terms, political decisions would be ruled not only by the fallible human 'reason' (akal) but by wahyu: the wisdom of divine radiance that found its clearest expression on earth in the writings of the Prophet. 
Significantly, though, he eschewed any attempt to join a co-ordinated movement that sought to establish a theocracy, instead deferring the prospect of being involved in such a campaign to an unspecified future date when a 'better organisation' might emerge. 'Right now I'm happy just working on my own, he explained, 'although I haven't given up [on politics' just yet. There actually are groups supporting a caliphate, like Hizbut Tahrir, ${ }^{10}$ but they are always staging demos with a black flag. They come from Palestine. I don't like the way they make those demos. They aren't allowed by the Qur'an.' Certainly, Hizbut Tahrir were a controversial group, and Syamsuddin could have had many legitimate reasons for deciding not to join them. Yet I also wondered whether, by preserving himself in a world where he could advocate his own vision of a 'straight path' without encountering any institutionalised dissent, Syamsuddin was better able to realise his fantasy of himself as a political figure than either democracy or the actual reality of theocratic advocacy would allow.

As with both Fio and Maznah, such behaviour is consistent with broader patterns of relationships in Syamsuddin's life - especially in the years since he had assumed his position as head of a household. He found it very difficult to be contradicted. Several of his earlier jobs had come to a premature end due to 'disagreements' with managers (a danger he now avoided by being the boss of his own business), and he was currently at his wits' end trying to deal with his father. The old man, still living in Syamsuddin's home town, had decided to marry a new wife some forty years his junior, and refused to be persuaded as to the disadvantages of such a situation. He was even willing to disown Syamsuddin's sister if she refused to accept the woman as her new step-mother. Syamsuddin found this infuriating. 'My father is so stubborn!', he complained, 'it's always his way, or no way!' At this point, Syamsuddin's wife caught my eye, and commented, in a tone that mixed wryness with weariness, that her husband had grown up to be precisely like his father. In a different way to Fio, then, Syamsuddin also found reconciling his desires with those of others to be an area of difficulty 
in his life, and in a way that appears to reflect a different response to (as well as a different position within) a family form that exemplifies the ideologies of patriarchal authority that once circulated throughout New Order Indonesia.

The better I got to know Syamsuddin, the more easily I could recognise how motivations and psychological dynamics related to authority and contradiction might be inflecting his encounters with and pronouncements about democracy. Certainly it was events associated with these issues that most readily became lightning rods for his criticism. Yet, unlike Fio or Maznah, who spoke in openly emotionalised tones of the horror and shame that democracy had created for them, Syamsuddin was much more disposed to presenting an experience charged with frustrations and affects in coldly intellectual terms. 'Under a caliphate the public will be able to know they are getting someone who is a good leader,' he once explained, 'because they know that the leader will be strict in his religion and thus have control. There wouldn't be general elections in this system, because the people are too stupid - they might elect anybody on any basis.' Here, Syamsuddin rehearsed a line of critique that has been levelled against democracies in all parts of the world, but had become particularly acute in the Riau Archipelago, a region dogged by allegations of 'poor human resource quality' associated with its indigenous Malay culture and fifty years of 'internal colonial' neglect (Long 2013: 173-205). 'A caliphate, he continued, invoking another widely echoed trope, 'would avoid the weaknesses of democracy. Currently people are too free. They have latched onto their freedom and are doing anything they want, but it is wrong to do anything that you want. Life has to be controlled - and this is where the people of Indonesia and especially these Riau Islands are really lacking.'

These are commonly voiced reasons for Indonesians to express alarm about democratisation, and although the extent to which Syamsuddin's fellow citizens really were doing 'anything they wanted' was overstated in his remarks, his analyses of voter quality and 
the need to set limits on citizens' freedoms are not without intellectual merit. What a personcentred ethnographic perspective allows us to see, however, is the way in which those widely circulating and not unpersuasive arguments may have become especially compelling to Syamsuddin because of the underlying personal meaning that political participation - which included making these very pronouncements - carried for him. If democracy had initially been attractive because it offered him the prospect of articulating his views in the public sphere in an uncompromising fashion, it was now, following his exit from the PKS, the public denouncement of democracy that allowed him to do that very same thing with impunity. Was it, then, my observational skills or my imagination that detected a note of glee in Syamsuddin's voice as he brought one of our conversations to a decisive close?

'I'm anti-democracy now. In fact, I think the democratisation of our state is one of the biggest problems we're facing. You know, Nick, there are some people in the West - and now people here are following suit - who say that democracy is the voice of God. ${ }^{11}$ But I disagree. Actually, if you're a Muslim, I don't think democracy can be allowed.'

\section{Conclusion: beyond the political consumer}

The three cases just presented stand as compelling evidence that Indonesians may turn away from democracy for reasons that are much more complicated and personal than a simple evaluation of whether or not they are the recipients of 'good governance' or experiences of 'unhappy consciousness'. Each case exemplifies a subjectivity shaped by imaginaries of how one should relate to others that are relatively widespread in contemporary Indonesia. Each has found the new ways of relating to themselves and others that are either demanded or encouraged by democratic forms of political life to be initially attractive but ultimately unpalatable, and in each case the rhetoric and concepts by which they come to echo that displeasure carries echoes of the language used to disparage liberal democracy in the pre- 
reform period. We can thus see how distinct elements of a widely circulating and heterogeneous set of Indonesian discourses concerning political life and citizenship have been emotionally particularised in ways that constitute distinct, radically individual, political subjectivities that nevertheless share a post-democratic sensibility and, though their actions and declarations, stoke the sense of democratic malaise within the Indonesian population as a whole. Ironically, then, democracy's success in creating a public sphere in which citizens are able to articulate their opinions is becoming a condition of possibility for its possible recession.

How, then, should we balance these in-depth but individualised insights against the significant body of survey data (summarised in Kurlantzick 2013) that identifies economic performance and corruption as the foremost concerns for Indonesians when they come to evaluate democracy? This issue is significant for interpreting the Riau Islands material, since 'corruption' and 'the economy' were the most immediately declared reasons that my interlocutors gave for having lost faith in democracy. Yet we must once again return to the question of subjectivity and ask why it is that such lines of argument - by now staples in the public sphere - might prove compelling to any given individual at any given time. As I suggested in my earlier discussion of Syamsuddin, well-recognised tropes may not always be latched onto because of a belief in their intellectual content, but rather/also because of their emotional tonality for the subject. Of the three Indonesians discussed above, it was perhaps Maznah whose volatility of opinion was the most illuminating in this regard. When speaking on the topic of 'democracy' or her involvement in campaigning, she would slide into invective, denouncing how terrible Indonesia's economy had become since democratisation, claiming that whilst unemployment had once only affected people of Javanese and Minangkabau ethnicity, now even Malays - her own ethnic group - were struggling to find jobs and being forced to work as manual labourers. Yet on other occasions, when we were 
discussing her children, or her family's history, she gave high praise to the reformasi leaders, especially Yudhoyono, under whose rule 'all of her children had been able to find jobs', and noted the improvements in the standards of living that Riau Islanders were beginning to enjoy. While cases such as Maznah's do not negate the very real economic hardships that some Indonesians had felt in the reformasi period, especially given the high levels of household debt engendered by a rapacious credit industry (see also Stavrakakis, this volume), they do reveal that citizens may actively express frustration with 'the economy' whilst also, on some level, acknowledging that the Indonesian economy is booming and that the Riau Islands Province is doing better even than the national average. In such cases, claims about the weak economy are not the perspicacious indictments of poor governance that they first appear to be. They instead serve as 'idioms of distress' (Nichter 1981), a means of expressing other, less easily or appropriately articulated disappointments with democracy, in a language that would resonate with those who heard it.

The practical implications of this argument are significant in a context where both scholars and major donor in the fields of democracy promotion and democracy assistance (notably USAID and AusAID) are emphasising increased funding for 'good governance' programs in order to 'consolidate' Indonesia's democratic institutions (Aspinall 2010a). This has been done on the understanding that the poor quality of current governance presents the most significant risk of democratic backsliding, both in terms of statecraft and popular opinion. Yet the material I have presented $\mathrm{n}$ this chapter suggests that such an assessment rests on a shallow understanding of the subjective difficulties that citizens have with democracy, many of which are likely to continue regardless of modest improvements in governance.

There are theoretical implications as well. By developing person-centred ethnographies of citizenship and political life that attend closely to the varieties of subjective 
investments that shape a population's apprehension of democracy and lie at the heart of the individual changes of heart that comprise, in toto, a broader pattern of 'democratic recession', my analysis not only offers political anthropology a new way of accounting for the feelings of melancholy, ambivalence and sadness that emerge after democratisation, but also a new focus for the study of democratic transitions. Placing the matrices of intersubjective relations in which subjects come to develop understandings of how to relate their own desires and interests to those of others at the heart of the enquiry leaves us better placed to anticipate and understand both the pleasures and pains of incipient democratisation. And while it is important to stress that these are not limited to family contexts, nor to social forms explicitly encouraged by authoritarianism, a provisional conclusion nevertheless seems clear: that the ways in which authoritarian regimes give rise to particular patterns of sociality and, in turn, particular patterns of psychodynamic engagement with the world can help us to understand why the euphoria of democracy is not always as long lasting as we, or our informants, might expect.

\section{Acknowledgements}

The research for this paper was generously supported by a British Academy Postdoctoral Fellowship and a Junior Research Fellowship at St Catharine's College, Cambridge. For their valuable feedback on earlier drafts, thanks to Marina Benjamin, Tina Pepler, and seminar audiences at Aarhus University, the University of Cambridge, the University of Copenhagen, the London School of Economics, and University College London.

\section{Notes}

\footnotetext{
${ }^{1}$ All personal names are pseudonyms.
} 
${ }^{2}$ The full extent of this 'trend' remains unclear. Some studies indicate that Indonesians' support for democracy has never been especially deep (Lussier and Fish 2012: 72-3) and that it has been falling steadily since at least 2003 (Kalinowski 2007: 368), whilst it is widely agreed that the period since 2008 has been marked by a rise in nostalgia for Suharto and in political support for once-reviled military strongmen. This trend reached its apogee in 2014, when former general Prabowo Subianto (perceived by many as a candidate standing for dedemocratisation) almost secured the Indonesian Presidency, attracting 46.9 per cent of the vote (Mietzner 2014). However, other studies suggest that even despite high levels of dissatisfaction with democratic institutions, public support for democracy remains stable, and as high as 83 per cent (ibid.: 124).

${ }^{3}$ The validity of this claim has been widely debated (see Bourchier and Legge 1994). Although some scholars have argued that constitutional democracy was incompatible with the culture and society of newly independent Indonesia, others believe its decline is better attributed to the inexperience of civilian politicians or its deliberate sabotage by the military.

${ }^{4}$ Whilst I am sympathetic to the critiques of the democratic-authoritarian dichotomy (see Merkel 2010: 20), my use of the terms reflects the strong emic distinction drawn between 'democracy' and 'authoritarianism' by Riau Islanders.

${ }^{5}$ This distinction between ethical and aspirational telos reflects the fact that some informants still felt a national duty to enact democracy as well as they could, whilst hoping for immanent political reform. 
${ }^{6}$ Chinese Indonesians were subjected to sustained racial discrimination throughout the New Order, but the levels of public awareness and remorse on this issue are not comparable to the South African case.

${ }^{7}$ The transmigration scheme involved relocating Indonesians from densely populated areas of Java to underpopulated areas elsewhere, where it was hoped they would set up productive farms. In practice, transmigrants in Lingga struggled to establish sustainable farming systems and many have since returned to Java.

${ }^{8}$ Mothers' curses are held to be especially powerful in the Malay World because of the tie of shared blood (Carsten 1995: 229).

${ }^{9}$ Some Riau Islanders did however see demonstrations as a sincere means of articulating 'the 'people's aspirations' - a key trope of reform (Graf 2010: 29).

${ }^{10}$ An international pan-Islamic organization, founded in 1953.

${ }^{11}$ Syamsuddin was probably referring to the ancient proverb 'vox populi, vox Dei', which had been widely popularised during Indonesia's initial period of parliamentary democracy in the 1950s (Feith 1963: 313). 


\section{References}

Aspinall, E. 2010a. Assessing Democracy Assistance: Indonesia. Madrid: FRIDE. . 2010b. The Irony of Success. Journal of Democracy 21, no. 2: 20-34.

Barker, J. 2007. Vigilantes and the State. In Identifying with Freedom: Indonesia after Suharto (ed.) T. Day, 87-94. Oxford: Berghahn.

Bourchier, D. 1994. The 1950s in New Order Ideology and Politics. In Democracy in Indonesia: 1950s and 1990s (eds) D. Bourchier and J. Legge, 50-62. Clayton: Centre of Southeast Asian Studies, Monash University.

Bourchier, D., and J. Legge, eds. 1994. Democracy in Indonesia: 1950s and 1990s. Clayton: Centre of Southeast Asian Studies, Monash University.

Brenner, S. A. 1998. The Domestication of Desire: Women, Wealth, and Modernity in Java. Princeton: Princeton University Press. 2007. Democracy, Polygamy, and Women in Post-Reformasi Indonesia. In Identifying with Freedom: Indonesia after Suharto (ed.) T. Day, 28-38. Oxford: Berghahn.

Bubandt, N. 2014. Democracy, Corruption and the Politics of Spirits in Contemporary Indonesia. Abingdon: Routledge.

Carothers, T. 2009. Stepping Back from Democratic Pessimism. Washington, DC: Carnegie Endowment for International Peace.

Carsten, J. 1995. The Substance of Kinship and the Heat of the Hearth: Feeding, Personhood, and Relatedness among Malays in Pulau Langkawi. American Ethnologist 22, no. 2: 223-241.

Chang, Y.-t., Y.-h. Chu, and C.-M. Park. 2007. Authoritarian Nostalgia in Asia. Journal of Democracy 18, no. 3: 66-80. 
Chapin, B. L. 2010. "We Have to Give”: Sinhala Mothers' Responses to Children's Expression of Desire. Ethos 38, no. 4: 354-368.

Crouch, H. 1994. Democratic Prospects in Indonesia. In Democracy in Indonesia: 1950s and 1990s (eds) D. Bourchier and J. Legge, 115-127. Clayton: Centre of Southeast Asian Studies, Monash University.

Davies, J. E. 2009. Considering "Self-Ful" Desire. Psychoanalytic Psychology 26, no. 3: $310-321$.

Day, T. 2007. Introduction: Identifying with Freedom. In Identifying with Freedom: Indonesia after Suharto (ed.) T. Day, 1-18. Oxford: Berghahn.

Diamond, L. 2008. The Spirit of Democracy: The Struggle to Build Free Societies Throughout the World. New York: Times Books.

Faubion, J. 2011. An Anthropology of Ethics. Cambridge: Cambridge University Press.

Feith, H. 1963. Dynamics of Guided Democracy. In Indonesia (ed.) R. T. McVey, 309-409. New Haven: HRAF Press. . [1962] 2007. The Decline of Constitutional Democracy in Indonesia. Singapore: Equinox.

Ferme, M. 1998. The Violence of Numbers: Consensus, Competition and the Negotiation of Disputes in Sierra Leone. Cahiers d'Etudes Africaines 150-152, no. xxxviii-2-4: 555-580.

Good, B. J. 2012. Theorizing the 'Subject' of Medical and Psychiatric Anthropology. Journal of the Royal Anthropological Institute 18, no. 3: 515-535.

Graf, A. 2010. Bahasa Reformasi: Political Rhetoric in Post-Suharto Indonesia. Wiesbaden: Harrassowitz Verlag. 
Hansen, T. B. 2012. Melancholia of Freedom: Social Life in an Indian Township in South Africa. Princeton: Princeton University Press.

Hartcher, P. 2013. Indonesia's Democracy at a Crossroads. The Sydney Morning Herald, 5 March.

Hasan, N. 2008. Reformasi, Religious Diversity, and Islamic Radicalism after Suharto. Journal of Indonesian Social Sciences and Humanities 1: 23-51.

Hickel, J. 2015. Democracy as Death: The Moral Order of Anti-Liberal Politics in South Africa. Berkeley: University of California Press.

Hollan, D. 2001. Developments in Person-Centred Ethnography. In The Psychology of Cultural Experience (eds) C. C. Moore and H. F. Mathews, 48-67. Cambridge: Cambridge University Press.

Hooker, V. M. 1993. New Order Language in Context. In Culture and Society in New Order Indonesia (ed.) V. M. Hooker, 272-293. Kuala Lumpur: Oxford University Press.

Kurlantzick, J. 2013. Democracy in Retreat: The Revolt of the Middle Class and the Worldwide Decline of Representative Government. New Haven: Yale University Press.

Long, N. J. 2013. Being Malay in Indonesia: Histories, Hopes and Citizenship in the Riau Archipelago. Singapore: NUS Press.

Lussier, D. N., and M. S. Fish. 2012. Indonesia: The Benefits of Civic Engagement. Journal of Democracy 23, no. 1: 70-84.

McVey, R. T. 1994. The Case of the Disappearing Decade. In Democracy in Indonesia: 1950s and 1990s (eds) D. Bourchier and J. Legge, 3-15. Clayton: Centre of Southeast Asian Studies, Monash University. 
Merkel, W. 2010. Are Dictatorships Returning? Revisting the 'Democratic Rollback' Hypothesis. Contemporary Politics 16, no. 1: 17-31.

Michelutti, L. 2007. The Vernacularization of Democracy: Political Participation and Popular Politics in North India. Journal of the Royal Anthropological Institute 13, no. 3: 639-656.

Mietzner, M. 2009. Indonesia in 2008: Democratic Consolidation in Soeharto's Shadow. Southeast Asian Affairs 2009: 105-123. 2014. How Jokowi Won and Democracy Survived. Journal of Democracy 25, no. 4: 111-125.

Milner, A. C. 1982. Kerajaan: Malay Political Culture on the Eve of Colonial Rule. Tucson: University of Arizona Press.

Nichter, M. 1981. Idioms of Distress: Alternatives in the Expression of Psychosocial Distress: A Case Study from South India. Culture, Medicine and Psychiatry 5, no. 4: 379-408.

Palmer, B. 2010. Services Rendered: Peace, Patronage and Post-Conflict Elections in Aceh. In Problems of Democratisation in Indonesia: Elections, Institutions and Society (eds) E. Aspinall and M. Mietzner, 286-306. Singapore: ISEAS.

Ratna Irtatik. 2012. Bebaskan Kemauan Anak; Berupaya Agar Istri Senang. Batam Pos, 31 August.

Simandjuntak, D. 2009. Milk Coffee at 10am: Encountering the State through Pilkada in North Sumatra. In State of Authority: The State in Society in Indonesia (eds) G. van Klinken and J. Barker, 73-94. Ithaca: Southeast Asia Program Publications, Cornell University.

Slater, D. 2007. The Ironies of Instability in Indonesia. In Identifying with Freedom: Indonesia after Suharto (ed.) T. Day, 95-104. Oxford: Berghahn. 
Soeharto. 2003 [1967]. Pancasila Democracy. In Indonesian Politics and Society: A Reader (eds) D. Bourchier and V. R. Hadiz, 37-41. London \& New York: RoutledgeCurzon.

Soetjipto Wirosardjono. 1994. Interpretation of the Current Scene. In Democracy in Indonesia: 1950s and 1990s (eds) D. Bourchier and J. Legge, 243-247. Clayton: Centre of Southeast Asian Studies, Monash University.

Tsuchiya, K. 1987. Democracy and Leadership: The Rise of the Taman Siswa Movement in Indonesia (trans. P. Hawkes). Honolulu: University of Hawai'i Press.

West, H. 2008. "Govern Yourselves!": Democracy and Carnage in Northern Mozambique. In Democracy: Anthropological Approaches (ed.) J. Paley, 97121. Santa Fe: SAR Press. 